\title{
Challenges in the diagnosis of neurofibromatosis type 1 (NF1) in young children facilitated by means of revised diagnostic criteria including genetic testing for pathogenic NF1 gene variants
}

\author{
Hildegard Kehrer-Sawatzki ${ }^{1}$ [ $\cdot$ David N. Cooper ${ }^{2}$
}

Received: 2 November 2021 / Accepted: 3 December 2021 / Published online: 20 December 2021

(c) The Author(s) 2021

\begin{abstract}
Neurofibromatosis type 1 (NF1) is the most frequent disorder associated with multiple café-au-lait macules (CALM) which may either be present at birth or appear during the first year of life. Other NF1-associated features such as skin-fold freckling and Lisch nodules occur later during childhood whereas dermal neurofibromas are rare in young children and usually only arise during early adulthood. The NIH clinical diagnostic criteria for NF1, established in 1988, include the most common NF1-associated features. Since many of these features are age-dependent, arriving at a definitive diagnosis of NF1 by employing these criteria may not be possible in infancy if CALM are the only clinical feature evident. Indeed, approximately $46 \%$ of patients who are diagnosed with NF1 later in life do not meet the NIH diagnostic criteria by the age of 1 year. Further, the 1988 diagnostic criteria for NF1 are not specific enough to distinguish NF1 from other related disorders such as Legius syndrome. In this review, we outline the challenges faced in diagnosing NF1 in young children, and evaluate the utility of the recently revised (2021) diagnostic criteria for NF1, which include the presence of pathogenic variants in the NF1 gene and choroidal anomalies, for achieving an early and accurate diagnosis.
\end{abstract}

\section{Introduction}

Neurofibromatosis type 1 (NF1, MIM\#162200) is an autosomal dominant inherited genodermatosis and tumour predisposition syndrome with an incidence of 1:3000 (Lammert et al. 2005). NF1 is caused by pathogenic variants in the NF1 gene on chromosome 17q11.2 and characterized by skin pigmentation anomalies such as café-au-lait macules (CALM) and skin-fold freckling, as well as dermal neurofibromas. Additionally, NF1 patients frequently have Lisch nodules, learning disabilities, attention deficits, hyperactivity, skeletal abnormalities, plexiform neurofibromas and optic pathway gliomas. The criteria for the diagnosis of NF1 were established by a National Institutes of Health (NIH) Consensus Conference in 1988 (Neurofibromatosis: conference

Hildegard Kehrer-Sawatzki

hildegard.kehrer-sawatzki@uni-ulm.de

1 Institute of Human Genetics, University Hospital Ulm, University of Ulm, Albert-Einstein-Allee 11, 89081 Ulm, Germany

2 Institute of Medical Genetics, Cardiff University, Heath Park, Cardiff CF14 4XN, UK statement: National Institutes of Health Consensus Development Conference 1988). They comprise the most common clinical features observed in NF1 (Table 1). Two or more of the 7 listed criteria must be met in a given individual for a definitive diagnosis of NF1 to be made. These diagnostic criteria have been widely used in the clinical routine since their original formulation in 1988. However, the discovery of other genetic disorders with clinical symptoms overlapping those of NF1 made the revision of these criteria necessary (Legius et al. 2021). The diagnostic criteria were also revised to facilitate the diagnosis of NF1 in young children who present with isolated CALM but no other disease manifestations or a family history of NF1 and hence do not meet the strict 1988 clinical diagnostic criteria. The revised diagnostic criteria for NF1 were published recently as an international consensus recommendation (Table 1) (Legius et al. 2021). They include the detection of a pathogenic variant in the $N F 1$ gene as a diagnostic criterion which allows for an early diagnosis of NF1 in oligosymptomatic children without a family history of the disease. The revised diagnostic criteria for NF1 also include choroidal anomalies as a new ophthalmic symptom with high sensitivity and specificity for NF1 which may facilitate the diagnosis of NF1 particularly in young oligosymptomatic children. 
Table 1 Comparison of the NIH diagnostic clinical criteria for NF1 from 1988 with the newly revised NF1 diagnostic criteria according to Legius et al. (2021)

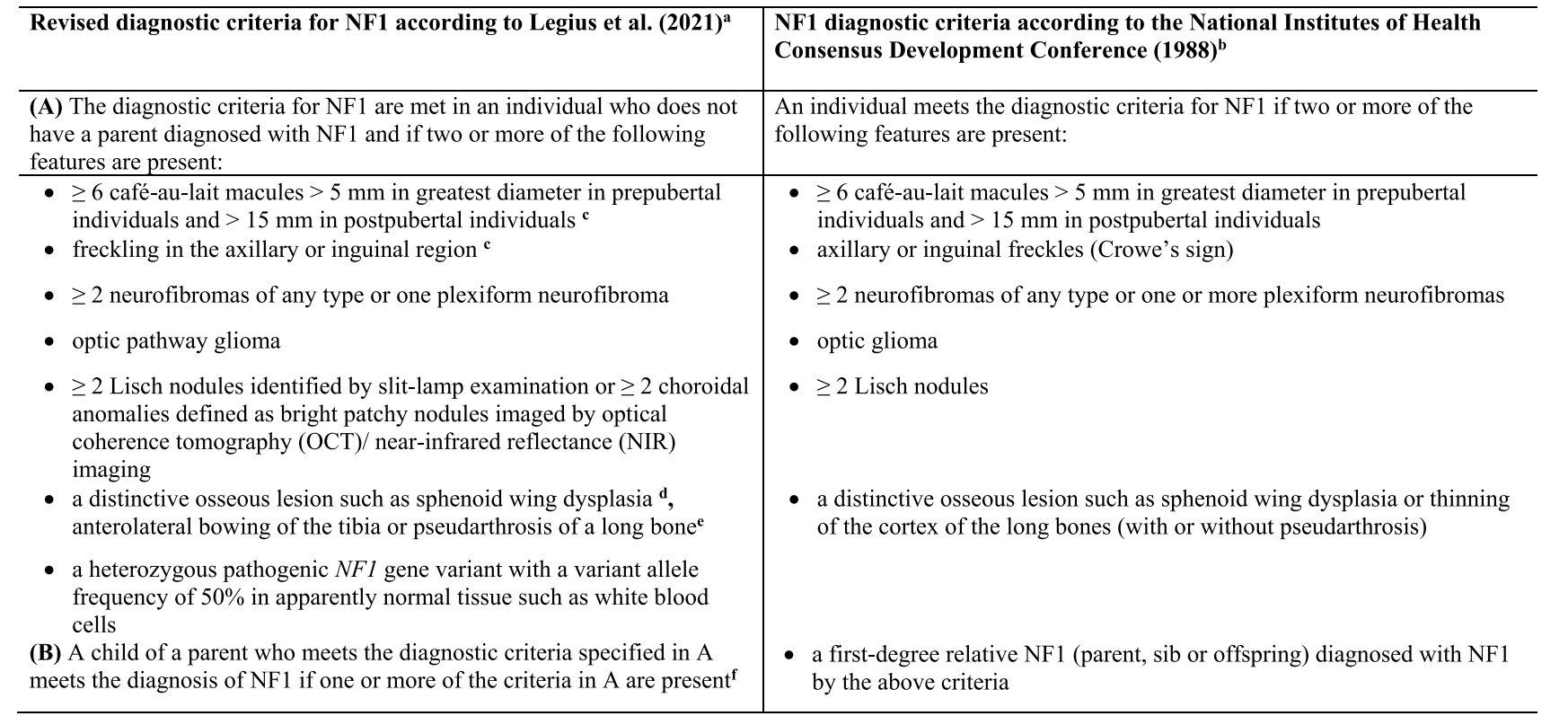

${ }^{a}$ Legius et al. (2021) Revised diagnostic criteria for neurofibromatosis type 1 and Legius syndrome: an international consensus recommendation. Genet Med 23:1506-1513

${ }^{b}$ Neurofibromatosis: conference statement: National Institutes of Health Consensus Development Conference (1988) Arch Neurol 45:575-578

${ }^{\mathrm{c}}$ If only café-au-lait macules and freckles are present, the diagnosis is most likely NF1 but exceptionally the individual might have another diagnosis such as Legius syndrome. At least one of the two pigmentary findings (café-au-lait macules or freckles) must be bilateral

${ }^{\mathrm{d}}$ Sphenoid wing dysplasia is not a separate criterion in case of an ipsilateral orbital plexiform neurofibroma

${ }^{\mathrm{e}}$ Thinning of the long bone cortex turned out not to be the primary lesion. Instead, anterolateral bowing of the lower limb and medullary canal narrowing as well as cortical thickening in the tibia and/or fibula is observed. Therefore, the orthopaedic criterion has been rephrased accordingly

${ }_{\mathrm{f}}^{\mathrm{f}}$ In the revised diagnostic criteria, only an affected parent but not affected siblings and offspring qualify as a criterion for NF1. If only siblings are affected, the diagnosis of CMMRD is possible. 'Offspring' was omitted because if an adult person has only one diagnostic criterion and one offspring meeting the diagnostic criteria, mosaic NF1 cannot be excluded

In this review, the challenges presented by the diagnosis of NF1 in young children are outlined, and the utility of the recently revised diagnostic criteria for NF1 (which include genetic testing) for overcoming these problems, are discussed.

\section{Challenges in the diagnosis of NF1 in young children and how the revised diagnostic criteria can help}

The vast majority of adult patients with NF1 meet the 1988 clinical diagnostic criteria listed in Table 1. The diagnosis of NF1 may however be more difficult in infants or toddlers if they present with isolated CALM and have no family history of the disease. Many NF1-associated features are agedependent. The first symptoms are generally CALM which may be present at birth or occur in the first year of life, often in the absence of other disease features. In the first year of life, multiple CALM are present in at least $82 \%$ of infants later diagnosed with NF1 (Huson et al. 1989). After CALM, the second most common feature in NF1 is axillary and/or inguinal freckling (Korf 1992; Nunley et al. 2009). However, axillary or inguinal freckles usually occur in children older than 2-3 years of age (Huson et al. 1989; Cnossen et al. 1998). Lisch nodules are present in the majority of adults with NF1, but only $5 \%$ of children younger than 3 years possess them (Lubs et al. 1991). Dermal neurofibromas frequently appear during puberty or young adulthood but are only very rarely detected in children younger than 3 years of age. Of the children with isolated CALM at initial presentation who are eventually diagnosed as having NF1, 76\% meet the clinical NIH NF1 criteria by the age of 4 years, whereas $94 \%$ meet the criteria by the age of 6 years, and $97-100 \%$ by the age of 8 years (DeBella et al. 2000; Nunley et al. 2009). However, approximately $46 \%$ of sporadic NF1 cases fail to meet the 1988 clinical diagnostic criteria by the age of 1 year (DeBella et al. 2000). Only by the age of 6-8 years do most children with NF1 meet the 1988 clinical diagnosis criteria (DeBella et al. 2000; Nunley et al. 2009). Until this 
age, a definitive diagnosis of NF1 may not be possible, a shortcoming that may well impede treatment and risk stratification. Earlier diagnosis of NF1 may be beneficial to both the affected children and their families. Genetic counselling could be offered to parents and other relatives earlier, and therapeutic interventions for learning disabilities, developmental problems or other complications could be initiated sooner (Cnossen et al. 1997).

Another problem is that the 1988 clinical diagnostic criteria for NF1 are not specific if children exhibit only CALM and skin-fold freckling. Other conditions such as Legius syndrome (MIM\#611431) or constitutional mismatch repair deficiency (CMMRD, MIM\#276300) are also associated with these clinical manifestations in children (Brems et al. 2007; Wimmer et al. 2017; Suerink et al. 2019; PerezValencia et al. 2020). These disorders are caused by pathogenic variants in genes other than NFI and are associated with quite different disease courses. Legius syndrome is caused by pathogenic variants of the SPRED1 gene whereas CMMRD is caused by pathogenic variants in one of four mismatch repair genes, namely $M L H 1, M S H 2, M S H 6$ or PMS2 (Brems et al. 2007; Wimmer et al. 2017).

In the following, the most frequent and less frequent NF1associated features in young children at risk of having NF1 are presented in greater detail.

\section{Frequent diagnostic features in children with NF1}

\section{Café-au-lait macules (CALM)}

One or 2 CALM occur in $2.5 \%$ of infants ( $<1$ year old) without a known underlying disorder (Alper et al. 1979). However, the presence of more than 3 CALM is rare, being detected in only $0.4 \%$ of healthy children $\leq 11$ years of age (Whitehouse 1966; Alper et al. 1979; Burwell et al. 1982) (Table 2). NF1 is the most frequent disorder associated with the occurrence of more than 5 CALM (Lalor et al. 2020).

In children presenting with isolated CALM at the time of first investigation, the predictive value of CALM for the diagnosis of NF1 has been assessed in several studies (DeBella et al. 2000; Nunley et al. 2009; Ben-Shachar et al. 2017). These analyses indicated that the higher the number of CALM, the more likely it is that a child has indeed NF1. According to the study of Ben-Shachar et al. (2017), 79\% of children younger than 14 months with $\geq 6$ isolated CALM and no other disease features were diagnosed with NF1 later in life as additional clinical features of NF1 became apparent. If comprehensive genetic testing for pathogenic NF 1 variants was applied, $88.4 \%$ of children younger than 14 months with $\geq 6$ isolated CALM were diagnosed with NF1 (Ben-Shachar et al. 2017). By contrast, none of the children younger than 14 months of age with fewer than 6 isolated CALM were diagnosed with NF1, at least according to the clinical diagnostic criteria. However, $16 \%$ of these children were diagnosed with NF1 by means of genetic testing (Ben-Shachar et al. 2017). These findings indicate two important points: First, the presence of $\geq 6$ CALM greatly increases the likelihood that children younger than 14 months have NF1. The risk for children with fewer than 6 CALM appears to be significantly lower, as confirmed by other studies (Korf 1992; Nunley et al. 2009). Further, these findings indicate that comprehensive genetic testing for pathogenic $N F 1$ variants increases the proportion of children presenting with isolated CALM, who can be diagnosed with NF1, by at least 10-16\%. Thus, including the detection of a pathogenic $N F 1$ variant among the revised diagnostic criteria has been very important in facilitating the early diagnosis of NF1 in this subgroup of children (Legius et al. 2021) (Table 1). This conclusion has been confirmed by the results of the studies of Guigliano et al. (2019) and Castellanos et al. (2020) as summarized in Table 3.

In addition to the number of CALM, the age of the child may also be an important factor in terms of a putative diagnosis of NF1. None of 50 children with fewer than 6 CALM who were 29 months or older were given a diagnosis of NF1 on the grounds that they did not have a pathogenic NF1 variant or did not meet the 1988 clinical diagnostic criteria (Ben-Shachar et al. 2017).

In addition to the number of CALM, their morphological appearance is also of some predictive value in determining

Table 2 Number of café-au-lait macules (CALM) in infants ( $<1$ year) and older children without a known underlying disorder as determined in 3 different studies

\begin{tabular}{lllll}
\hline & Alper et al. (1979) & Whitehouse (1966) & Burwell et al. (1982) \\
\hline Age of children analysed & Newborn-1 year & 1 Month-5 years & 4-11 years & $\Sigma=5548$ \\
Total number of children & 4641 & 365 & 542 & $\Sigma=303(5.5 \%)$ \\
Children with 1 CALM & $88(1.9 \%)$ & $69(18.9 \%)$ & $146(26.9 \%)$ & $\Sigma=71(1.3 \%)$ \\
Children with 2 CALM & $26(0.6 \%)$ & $15(4.1 \%)$ & $30(5.5 \%)$ & $\Sigma=374(6.7 \%)$ \\
Children with 1 or 2 CALM & $114(2.5 \%)$ & $84(23 \%)$ & $176(32 \%)$ & $\Sigma=22(0.4 \%)$ \\
Children with $\geq 3$ CALM & $10(0.2 \%)$ & $1(0.3 \%)$ & $11(2 \%)$ & \\
\hline
\end{tabular}


Table 3 Studies that have investigated children with isolated CALM but no other NF1-associated disease features and without an affected firstdegree relative by means of comprehensive genetic testing of the NF1 gene (and the SPRED1 gene)

\begin{tabular}{|c|c|c|c|c|c|c|}
\hline $\begin{array}{l}\text { Total number of } \\
\text { patients investi- } \\
\text { gated }\end{array}$ & Age of the patients & $\begin{array}{l}\text { Number } \\
\text { of CALM }\end{array}$ & $\begin{array}{l}\text { Number of patients } \\
\text { with pathogenic vari- } \\
\text { ants in the } N F 1 \text { gene }\end{array}$ & $\begin{array}{l}\text { Number of patients } \\
\text { with pathogenic vari- } \\
\text { ants in the SPRED1 } \\
\text { gene }\end{array}$ & $\begin{array}{l}\text { Number of patients } \\
\text { without a pathogenic } \\
\text { variant }\end{array}$ & References \\
\hline 44 & $\leq 9$ Years & $\geq 6$ & $28(63.6 \%)$ & $1(2.3 \%)$ & $15(34.1 \%)$ & $\begin{array}{l}\text { Giugliano et al. } \\
\text { (2019) }\end{array}$ \\
\hline 71 & $\begin{array}{l}0-7 \text { Years }(N=42) \text {; } \\
>7 \text { Years }(N=8) \text {; } \\
\text { age unknown } \\
\quad(N=21)\end{array}$ & $\geq 6$ & $34(47.9 \%)^{\mathrm{a}}$ & $3(4.2 \%)^{\mathrm{b}}$ & $25(35.2 \%)$ & $\begin{array}{l}\text { Castellanos et al. } \\
\text { (2020) }\end{array}$ \\
\hline 95 & $\leq 14$ Months & $\geq 6$ & $84(88.4 \%)$ & Not investigated & $11(11.6 \%)$ & $\begin{array}{l}\text { Ben-Shachar et al. } \\
(2017)^{c}\end{array}$ \\
\hline 65 & $\begin{array}{l}>14 \text { Months } \\
\text { and } \leq 29 \text { months }\end{array}$ & $\geq 6$ & $45(69.2 \%)$ & Not investigated & $20(30.8 \%)$ & $\begin{array}{l}\text { Ben-Shachar et al. } \\
(2017)^{c}\end{array}$ \\
\hline 38 & $\leq 14$ Months & $<6$ & $6(15.8 \%)$ & Not investigated & $32(84.2 \%)$ & $\begin{array}{l}\text { Ben-Shachar et al. } \\
(2017)^{c}\end{array}$ \\
\hline
\end{tabular}

${ }^{\text {a } I n}$ addition to 34 pathogenic $N F 1$ variants, 7 patients with missense $N F 1$ variants of unknown significance (VUS) were identified. Thus, the total number of $N F 1$ variants identified was $N=41(57.8 \%)$

${ }^{\mathrm{b}}$ In addition to 3 pathogenic SPRED1 variants, two patients with SPRED1 variants of unknown significance (VUS) were identified. Thus, the total number of SPRED1 variants identified was $N=5$ (7\%)

${ }^{\mathrm{c}}$ In this study, patients under suspicion of segmental NF1 were excluded but children were not tested for possible generalized mosaic NF1

whether a child is at higher or lower risk of having NF1. Typical CALM present with homogeneous pigmentation and regular borders. By contrast, atypical CALM exhibit irregular margins and ragged borders. Children who were 29 months or older with atypical CALM had a very low risk of having molecularly or clinically confirmed NF1 (BenShachar et al. 2017). Furthermore, patients with NF1 who were found to harbour pathogenic NF1 variants had atypical CALM six-fold less frequently than individuals without pathogenic NF1 variants (Ben-Shachar et al. 2017). This concurs with the results of Nunley et al. (2009) who observed that $47 \%$ of children with isolated typical CALM were diagnosed as having NF1 later in life by means of clinical criteria, whereas only $5 \%$ of children with atypical CALM developed NF1. Comprehensive genetic testing for pathogenic NF1 variants, as included now in the revised criteria for NF1, may facilitate the diagnosis in patients with atypical CALM in the absence of further NF1-associated disease features.

\section{Skinfold freckling}

Axillary and inguinal freckles are generally $1-3 \mathrm{~mm}$ in diameter and appear as tiny brown spots, often in groups. In contrast to CALM, these freckles become apparent later in childhood. The youngest patients exhibiting freckles are 2-3 years old (Huson et al. 1989; Cnossen et al. 1998). In children suspected of having NF1 on the grounds that they exhibit $\geq 6$ isolated CALM at initial presentation, the second most common disease feature used to establish the diagnosis of NF1 is axillary and/or inguinal freckling, occurring in $77 \%$ of patients (Nunley et al. 2009). By the age of 6 years, $81 \%$ of patients with NF1 exhibit freckling and by the age of 7 years almost 90\% have freckling (Obringer et al. 1989; DeBella et al. 2000). Since freckles usually become visible only after the age of 2-3 years, they do not facilitate the diagnosis in younger children presenting with isolated CALM and no family history of NF1. Until the appearance of skin-fold freckling in this group of children, a definitive diagnosis of NF1 is not possible without molecular testing for a pathogenic $N F 1$ variant.

\section{Lisch nodules}

Lisch nodules are benign hamartomas of the iris. Isolated Lisch nodules are very rarely seen in individuals from the general population (reviewed by Cassiman et al. 2013). By contrast, the vast majority of adult NF1 patients have multiple Lisch nodules (Huson et al. 1989; Lubs et al. 1991). Hence, Lisch nodules are a highly specific diagnostic criterion (Lubs et al. 1991). It has been shown that light irides harbour significantly more Lisch nodules than dark irides what may be explicable in terms of the photo-protective effects of pigmentation (Boley et al. 2009). Furthermore, Lisch nodules are primarily located in the inferior hemifield (half) of the iris, irrespective of its colour. These findings suggest that UV radiation and DNA damage may play a role in the pathogenesis of Lisch nodules (Boley et al. 
2009). Although Lisch nodules appear during childhood, only $5 \%$ of children younger than 3 years have them (Lubs et al. 1991). The estimated prevalence of Lisch nodules is $42 \%$ among children with NF1 who are 3-5 years old and $55 \%$ in children aged 5-6 years (Lubs et al. 1991). Another study has reported Lisch nodules in 52\% of children with $\mathrm{NF} 1$; the mean age at presentation of Lisch nodules in these patients was 8.8 years with a standard deviation of 3.6 years (Cnossen et al. 1998). Thus, Lisch nodules are an important diagnostic feature of NF1 in older children but may not allow for a definitive diagnosis of NF1 in infants with multiple CALM. Lisch nodules are not however observed in patients with Legius syndrome and hence may facilitate the differential diagnosis by means of clinical criteria.

\section{Choroidal anomalies}

Fundus examination by means of near-infrared reflectance with a scanning laser ophthalmoscope (NIR) and ocular coherence tomography (OCT) have indicated that choroidal anomalies are frequent in patients with NF1 (Yasunari et al. 2000; Viola et al. 2012; Goktas et al. 2014; Parrozzani et al. 2015; Vagge et al. 2015; Cassiman et al. 2017; Tucci et al. 2017). Choroidal anomalies appear as ovoid, bright patches or nodules consisting of proliferating Schwann cells and melanocytes arranged in concentric rings around axons (Viola et al. 2012). Choroidal involvement has previously been considered to be a rare finding in NF1, due to the fact that these lesions are asymptomatic and not detectable by conventional ophthalmoscopy or fluorescein angiography.

The presence and number of choroidal anomalies (CA) is age-dependent; their prevalence is lower in children with NF1 than in adults with the disease. Whilst CA are observed in $86-100 \%$ of adult NF1 patients (Yasunari et al. 2000; Viola et al. 2012), the prevalence of CA in children with NF1 younger than 12 years is $60.5-78.9 \%$ (Viola et al. 2012; Goktas et al. 2014; Parrozzani et al. 2015; Vagge et al. 2015).

CA appear to be as frequent as, or even more frequent than, Lisch nodules in children with NF1 (Viola et al. 2012; Parrozzani et al. 2015). Most importantly, CA can be detected in children as young as 2 years of age (Vagge et al. 2015). By contrast, in many children with NF1, Lisch nodules appear only later, around the age of 3-5 years (Lubs et al. 1991).

CA are only rarely detected or not all in healthy controls (Viola et al. 2012; Goktas et al. 2014; Parrozzani et al. 2015; Vagge et al. 2015; Cassiman et al. 2017). If CA are present in healthy controls, they represent single lesions (Cassiman et al. 2017). In NF1 patients, CA are generally present as multiple lesions; $56 \%$ of patients exhibit more than $4 \mathrm{CA}$ (Cassiman et al. 2017). Multiple CA are not detected in patients with Legius syndrome (Cassiman et al. 2017; Tucci et al. 2017) and only two of 19 patients with Legius syndrome were found to have a single choroidal anomaly (Cassiman et al. 2017; Tucci et al. 2017). These findings imply that CA are very rare in patients with Legius syndrome and may represent an important distinguishing diagnostic feature. Further, since CA are present at an early stage, they may facilitate the diagnosis of NF1 in children with isolated CALM who do not meet the 1988 clinical diagnostic criteria. Therefore, CA have been included in the revised criteria for the diagnosis of NF1 (Table 1) (Legius et al. 2021). The NIR method is non-invasive and generally well tolerated by children. However, the success of the investigation is very much dependent upon the degree of cooperation given by the child. Parrozzani et al. (2015) investigated 160 children with a mean age of 8 years (range $2-13$ years) by means of NIR and the feasibility rate was found to be $82 \%$. Of these 160 children, 119 were already diagnosed with NF1 since they met the clinical diagnostic criteria and $72(60.5 \%)$ of them had CA. The remaining 41 children were suspected to have NF1 although they did not meet the NIH criteria. One of them was a 2-year old boy with more than 5 CALM but no other symptoms of NF1. Since this boy had CA, he was diagnosed with NF1. Likewise, Vagge et al. (2015) detected $\mathrm{CA}$ in a 2-year old child, indicative of the early appearance of this diagnostic feature of NF1. So far, there are no indications for the assumption that CA would cause clinical complications during the course of the disease. Since CA have a high specificity and sensitivity for NF1, they have been added as an ophthalmic criterion to the revised diagnostic criteria for NF1 (Legius et al. 2021) (Table 1).

\section{Plexiform neurofibromas and optic pathway gliomas}

Plexiform neurofibromas (PNFs) are congenital lesions characterized by tumour cells that spread along multiple fascicles of the nerve, leading to a diffuse mass of thickened nerve fibres embedded within a proteinaceous matrix. PNFs may be located superficially and/or internally and hence only detectable by MRI scans, particularly in young children. The estimated prevalence of externally visible or palpable plexiform neurofibromas (but not internal PNF) in children with NF1 is 26.6-30\% (Huson et al. 1989; Cnossen et al. 1998; Prada et al. 2012). Whole-body MRI of 65 children and adolescents with NF1 aged between 1.7 and 17.6 years indicated that $37(57 \%)$ had internal PNF which were asymptomatic in $20(31 \%)$ of the patients (Nguyen et al. 2011). In approximately $50 \%$ of all children with PNF, the age at clinical identification of the tumours is $0-3$ years (Prada et al. 2012). Since PNFs occur in the vast majority of cases in the context of NF1, they are a rather specific diagnostic criterion for NF1. 
Optic pathway gliomas (OPGs) are low grade astrocytomas observed in 14-20\% of patients with NF1 as determined by neuroimaging (Listernick et al. 1994; Blanchard et al. 2016; Friedrich and Nuding, 2016). NF1-associated OPGs are most often diagnosed during childhood. Children $\leq 6$ years of age have the highest risk to develop a symptomatic OPG (Listernick et al. 1994). The mean age at diagnosis of a symptomatic OPG was 4.2 years (Listernick et al. 1994), 4.6 years (Trevisson et al. 2017), 5.1 years (Nicolin et al. 2009) and 7.6 years (Friedrich and Nuding 2016). Asymptomatic OPGs are often diagnosed later in life, with a mean age at diagnosis of 5.3 years (Listernick et al. 1994), 5.9 years (Trevisson et al. 2017), 11.6 years (Friedrich and Nuding 2016). Visual acuity, strabismus, exophthalmus and proptosis are the most common symptoms caused by these tumours (Listernick et al. 2007; Friedrich and Nuding 2016). A proportion of OPGs are already present at birth and their detection in young children by MRI may facilitate the diagnosis of NF1. Taken together, PNFs and optic pathway gliomas are important diagnostic features in young children with NF1.

\section{Less common disease features in children with NF1}

\section{Long-bone dysplasia}

Long-bone dysplasia, seen in 5\% of patients with NF1 typically involves the tibia and frequently presents with anterolateral bowing that may progress to fracture (Riccardi 1981). In addition to the tibia, fibula, radius and ulna are also potential sites of dysplasia even though less commonly. Longbone dysplasia is most often unilateral, evident in the first year of life, and usually not associated with a neurofibroma (Stevenson et al. 1999). Congenital anterolaterally bowed tibia without pseudarthrosis is observed in 3-4\% of young children with NF1 (Friedman and Birch 1997). It may be apparent at birth but in most cases, it is recognized months later albeit within the first year of life. Remarkably, tibial dysplasia with pseudarthrosis is caused by double inactivation of the NFI gene (Stevenson et al. 2006; Sant et al. 2015). Thus, these osseous lesions as well as other frequent clinical symptoms in NF1 such as CALM, neurofibromas and other tumours arise according to the two-hit model of tumorigenesis (Serra et al. 1997, 2000; Maertens et al. 2007; De Schepper et al. 2008; reviewed by Brems et al. 2009). The prevalence of patients with NF1 among patients with congenital arthrosis of the tibia has been estimated to be $85 \%$ (Van Royen et al. 2016). Germline NF1 pathogenic variants are present in patients with NF1 but are absent in patients with congenital pseudarthrosis of the tibia without NF1 thereby differentiating these patient groups (Zhu et al. 2019).
The NIH diagnostic criteria for NF1 from 1988 included the criterion: "thinning of the long bone cortex with or without pseudarthrosis" (Table 1). However, thinning of the long bone cortex turned out not to be the primary lesion (Stevenson et al. 2007). Instead, anterolateral bowing of the lower limb and medullary canal narrowing as well as cortical thickening in the tibia and/or fibula is observed (Stevenson et al. 2007). In the revised version of the diagnostic criteria, the orthopaedic criterion has been rephrased accordingly (Table 1).

\section{Sphenoid wing dysplasia}

Unilateral dysplasia of the greater wing of the sphenoid bone is one of the most distinctive craniofacial lesions in NF1, being observed in 3-11\% of cases (reviewed by Alwan et al. 2005). Sphenoid wing dysplasia (SWD) is congenital but becomes clinically apparent later in life, frequently before the age of 2 years. SWD can be asymptomatic and is diagnosed by skull radiographs or CT scans. SWD is relatively rare in the general population, and over $50 \%$ of cases are associated with NF1 (reviewed by Chauvel-Picard et al. 2020). SWD may become progressive and cause disruption of the orbit and consequent pulsating exophthalmos. Abnormal growth of the skull associated with sphenoid wing lesions in children with NF1 may also lead to progressive facial deformities (Jacquemin et al. 2002). SWP is thought to result from a primary ossification defect with poor mesodermal development and bone formation (reviewed by Alwan et al. 2005; Chauvel-Picard et al. 2020). However, SWP may also occur concurrent with orbital-periorbital plexiform neurofibromas (reviewed by Avery et al. 2017). According to the newly revised diagnostic criteria for NF1, sphenoid wing dysplasia is not a separate diagnostic criterion in case of an ipsilateral orbital plexiform neurofibroma (Table 1).

\section{Genetic testing in NF1}

New in the revised version of the diagnostic criteria is the inclusion of the detection of a pathogenic $N F 1$ gene variant as a separate diagnostic criterion (Legius et al. 2021).

Variants identified in the NF1 gene are classified as pathogenic according to the guidelines developed by the American College of Medical Genetics and Genomics, the Association for Molecular Pathology and the College of American Pathologists (Richards et al. 2015). The NF1 gene is relatively large, encompassing $\sim 350 \mathrm{~kb}$ and 55 constitutive exons as well as five alternatively spliced exons. $N F 1$ encodes neurofibromin, a multifunctional protein with at least 6 different functional domains involved in the regulation of various signalling pathways (reviewed by Bergoug et al. 2020). More than 3600 different pathogenic NFI 
variants have now been reported by The Human Gene Mutation Database (HGMD; http://www.hgmd.org/); these are located across the gene coding regions as well as within the introns thereby interfering with the splicing process (Stenson et al. 2020). Whilst some 31 different pathogenic NF1 variants exhibit a prevalence of $\geq 0.5 \%$ among NF1 patients, it has been estimated that approximately $46 \%$ of NF1 patients carry extremely rare or private pathogenic $N F 1$ gene variants (Koczkowska et al. 2018, 2019, 2020). In addition, copy number variants of single and multiple $N F 1$ exons have been identified, as well as deletions spanning the entire NF1 gene which are observed in $5-11 \%$ of all NF1 patients (Messiaen, 2020; Kehrer-Sawatzki and Cooper 2021).

Genetic testing in NF1 is complicated by the large size of the gene with its long stretches of intronic DNA, the extensive allelic heterogeneity (i.e. the large number of different pathogenic and likely pathogenic $N F 1$ variants) and the challenging interpretation of potentially pathogenic $N F 1$ variants, particularly missense and in-frame deletion/insertion variants. However, a comprehensive genetic testing protocol can ensure a high detection rate of the pathogenic variants residing within or involving the $\mathrm{NFl}$ gene as well the accurate and reliable interpretation of their molecular consequences (Messiaen et al. 2000; Wimmer et al. 2006; Pros et al. 2008; Valero et al. 2011; Sabbagh et al. 2013; Imbard et al. 2015; Pasmant et al. 2015; Evans et al. 2016; Pasmant and Vidaud 2016; Messiaen 2020). Such a protocol should include RNA analysis by means of cDNA sequencing, the sequence analysis of the coding sequence and intron/exon boundaries of the NF1 gene, as well as the copy number analysis of NF1 exons and whole gene deletions (Messiaen et al. 2000; Wimmer et al. 2006; Pros et al. 2008; Valero et al. 2011; Sabbagh et al. 2013; Pasmant et al. 2015; Evans et al. 2016; Pasmant and Vidaud 2016; Giugliano et al. 2019; Castellanos et al. 2020; Messiaen 2020). By means of a comprehensive mutation testing protocol in $361 \mathrm{NF} 1$ patients with more than pigmentary diagnostic criteria, a potentially pathogenic $N F 1$ variant was identified in 166/171 (97\%) of familial cases and 182/190 (96\%) of sporadic cases (Evans et al. 2016). If class 3 variants of unknown pathogenicity according to Plon et al. (2008) and Richards et al. (2015) had not been included, the pathogenic variant detection rate decreased to $154 / 171$ (90\%) in familial cases and 175/190 $(92 \%)$ in sporadic cases. Similarly high mutation detection rates have been obtained in other studies that employed comprehensive genetic testing of the NF1 gene (Messiaen et al. 2000; Valero et al. 2011; Sabbagh et al. 2013; Guigliano et al. 2019). cDNA sequencing is superior to standard exon sequencing since a broader spectrum of pathogenic variants can be identified, including deep intronic variants. Further, it improves the detection of those pathogenic missense variants that affect splicing (Messiaen et al. 2000; Evans et al. 2016; Pasmant and Vidaud, 2016).
The recruitment of genetic testing to make possible a definitive diagnosis of NF1 is particularly important in children and young adults with isolated multiple CALM but without a family history of the disease (Tsang et al. 2012; Yao et al. 2016). This assertion is supported by the study of Evans et al. (2016) who analysed 71 individuals with $\geq 6$ CALM with or without freckling, but no other NF1 diagnostic criterion, who also lacked a parent with any NF1 criterion and were $<20$ years of age. Of these 71 individuals, $44(62 \%)$ harboured a clearly pathogenic NF1 variant, 3 had $N F 1$ variants of uncertain pathogenicity, $6(8.5 \%)$ a pathogenic SPREDI variant whilst 18 (25.3\%) did not possess a disease-causing variant in either SPRED1 or NF1. Thus, the likelihood that a child with $\geq 6$ CALM with or without freckling and no other NF1 criterion has non-mosaic NF1 is $62-66 \%$. This conclusion is in accord with the results of other studies that determined the pathogenic $N F 1$ variant detection rate in children with isolated multiple CALM and no family history of the disease (Table 3 ). A negative testing result for a pathogenic $N F 1$ variant reduces the likelihood to have constitutional (non-mosaic) NF1 to $11 \%$ in children and young adults with $\geq 6$ CALM with or without freckling, but no other NF1 diagnostic criterion (Evans et al. 2016).

Genetic testing performed to detect pathogenic $N F 1$ variants may also facilitate the diagnosis in some families with spinal NF1 (Burkitt Wright et al. 2013) or patients with the pathogenic in-frame deletion in NFI exon 17 at position c.2970-2972 delAAT (p.Met992del) which is associated with typical pigmentary features of NF1, but not with neurofibromas (Upadhyaya et al. 2007; Quintans et al. 2011; Koczkowska et al. 2019). Likewise, patients with various different $N F 1$ missense pathogenic variants at amino acid residue Arg 1809 have multiple CALM with or without freckling and rarely Lisch nodules, but do not exhibit neurofibromas (Pinna et al. 2015; Rojnueangnit et al. 2015; Santoro et al. 2015). In these cases, the genetic testing isn't simply to facilitate the clinical diagnosis, but also to allow a prediction to be made about the clinical phenotype from the mutant genotype detected. NF1 patients with these lesions may not meet the 1988 clinical diagnostic criteria, particularly during childhood. However, they would do so if the 2021 criteria would be applied including genetic testing. By contrast, $95 \%$ of individuals with classic NF1 fulfil two or more of the 1988 clinical diagnostic criteria (not taking family history into account) by $\geq 9$ years of age (DeBella et al. 2000). Individuals with p.Arg 1809 or p.Met992del pathogenic variants are less likely than NF1 patients of the same age who harbour other $N F 1$ variants to fulfil the 1988 clinical criteria at $\geq 9$ years of age (Rojnueangnit et al. 2015). In the same vein, pathogenic missense variants affecting NF1 residue Met1149 are associated with a mild phenotype characterized by the lack of NF1-associated tumours (Koczkowska et al. 2020). These authors reported that $16.7 \%$ of 
patients with pathogenic missense variants affecting residue Met1 149 who were older than 9 years did not fulfil the 1988 clinical diagnostic criteria (Koczkowska et al. 2020). In these families, genetic testing is therefore important to confirm the clinical diagnosis and identify at-risk relatives (Jett and Friedman 2010).

Even though genetic testing may facilitate the diagnosis of NF1 in young oligosymptomatic children without a family history of the disease, some parents and physicians may object to genetic testing for practical or financial reasons and might instead opt to wait until further diagnostic symptoms may (or may not) appear.

\section{Differential diagnosis of NF1 versus Legius syndrome and CMMRD}

Differential diagnosis is particularly difficult in children with multiple isolated CALM without a family member with multiple CALM, NF1 or Legius syndrome. These children may not be affected by NF1 but instead by Legius syndrome or less frequently by another RASopathy such as Noonan syndrome with multiple lentigines (formerly known as LEOPARD syndrome, MIM\#151100) or Constitutive mismatch repair deficiency (CMMRD) (Brems et al. 2007; Shah et al. 2010; Santoro et al. 2014; Santos et al. 2016; Wimmer et al. 2017; Suerink et al. 2019; Anderson 2020; Jha et al. 2020; Perez-Valencia et al. 2020).

NF1 and Legius syndrome are the RASopathies with the most pronounced overlap in clinical symptoms. RASopathies constitute a group of genetic disorders that are caused by germline pathogenic variants affecting RAS-mitogen activated protein kinase (MAPK) pathway genes leading to RAS/MAPK pathway dysregulation (reviewed by Rauen 2013). To improve the differential diagnosis of NF1, the detection of pathogenic variants in the NFI gene has been included among the revised diagnostic criteria for NF1 (Table 1) (Legius et al. 2021). In children with multiple isolated CALM and without affected family members, genetic testing indicated a detection rate of pathogenic $N F 1$ variants in the range of $48 \%$ up to $88 \%$, depending on the age of the children and the number of CALM (Ben-Shachar et al. 2017; Giugliano et al. 2019; Castellanos et al. 2020) (Table 3).

\section{Legius syndrome}

Legius syndrome (MIM\#611431) is characterized by the occurrence of CALM with or without axillary or inguinal freckles and therefore resembles NF1. Learning disabilities, attention deficits and hyperactivity may also occur in patients with Legius syndrome even though they are generally less frequent and less severe than in NF1 (Brems and Legius 2013; Denayer and Legius 2020). Other NF1-associated features such as Lisch nodules, neurofibromas, NF1-specific bone lesions, optic pathway gliomas, and malignant peripheral nerve sheath tumours are however absent in patients with Legius syndrome (Brems et al. 2007, 2012; Messiaen et al. 2009; Pasmant et al. 2009; Spurlock et al. 2009; Laycock-van Spyk et al. 2011; Brems and Legius 2013; Denayer and Legius 2020).

Legius syndrome has been estimated to occur with a prevalence of 1:46,000-1:75,000 and is caused by pathogenic variants in the SPRED1 gene located on chromosome 15q13.2 (Brems et al. 2007, 2012; Messiaen et al. 2009; Pasmant et al. 2009; Spurlock et al 2009; Laycock-van Spyk et al. 2011). The mode of inheritance is autosomal dominant and $65 \%$ of patients with Legius syndrome have a family history of the disease. SPREDI encodes the sproutyrelated EVH1 domain-containing protein 1. Via its EVH1 domain, the SPRED1 protein binds to neurofibromin, the protein product of the $N F 1$ gene, thereby recruiting it to the plasma membrane. Neurofibromin is a negative regulator of RAS and its interaction with SPRED1 leads to the downregulation of the RAS-MAPK signal transduction pathway (Wakioka et al. 2001; Stowe et al. 2012; Dunzendorfer-Matt et al. 2016; Lorenzo and McCormick 2020).

In young children presenting with CALM with or without freckling and no other NF1-associated features or a family history of the disease, the differential diagnosis between NF1 and Legius syndrome is not possible by means of the 1988 clinical diagnostic criteria. However, an early differential diagnosis is very important in terms of patient care and risk stratification since Legius syndrome is not associated with the tumour phenotype seen in NF1.

In families with an autosomal dominant phenotype of CALM with or without freckles but without other NF1-associated disease features or a pathogenic $N F 1$ gene variant, $19 \%$ have a mutation in the SPREDI gene (Messiaen et al. 2009; Brems et al. 2012). It has been estimated that 1-8.5\% of patients with multiple CALM with or without freckling but no other NF1 diagnostic features, have Legius syndrome (Evans et al. 2016; Brems and Legius, 2013; Pasmant et al. 2015; Bernier et al. 2016).

Approximately $50 \%$ of patients with Legius syndrome meet the 1988 clinical diagnostic criteria for NF1 since they have $\geq 6$ CALM with freckles or have $\geq 6$ CALM without freckles and a family member with CALM and freckles (Messiaen et al. 2009). Approximately 1-4\% of patients with multiple CALM who meet the 1988 clinical diagnostic criteria for NF1 have Legius syndrome since they harbour SPRED1 pathogenic variants (Brems et al. 2012). Consequently, the diagnostic criteria for NF1 had to be revised (Legius et al. 2021). Concomitantly, the diagnostic criteria for Legius syndrome were formulated for the first time by an international board of experts (Table 4) (Legius et al. 2021). It was most important to be able to distinguish between the 
two conditions since they differ markedly in terms of the severity of their clinical manifestations. In contrast to NF1, frequent surveillance for tumours is not necessary in children and adults with Legius syndrome (Denayer and Legius 2020).

It is important to add that in some patients with multiple isolated CALM, pathogenic variants are not found in either the SPREDI gene or the NFI gene by the molecular testing of blood. In sporadic patients, the underlying cause may be somatic mosaicism for a pathogenic NFI or SPREDI variant that is present only in melanocytes and absent from blood cells (Maertens et al. 2007; Legius et al. 2021). To provide guidance for the correct diagnosis, diagnostic criteria for mosaic NF1 and mosaic Legius syndrome have also been formulated and published as an international consensus recommendation (Legius et al. 2021). It has been estimated that $\sim 10 \%$ of sporadic NF1 patients have mosaic NF1 caused by postzygotic NF1 mutations that are absent from, or present in, a very low proportion of blood lymphocytes (Messiaen et al. 2000). This may be concluded from the pathogenic variant detection rate determined by means of comprehensive genetic testing including the genomic DNA and cDNA sequencing of the $N F 1$ gene as well as the assessment of copy number variants of single and multiple $N F 1$ exons and entire NF1 gene deletions (Messiaen et al. 2000). Mosaicism has also been observed in Legius syndrome but it would appear to be rare (Jobling et al. 2017). The clinical suspicion of mosaicism justifies genetic testing for Legius syndrome and NF1, as now included in the newly formulated diagnostic criteria for the mosaic forms of both conditions (Legius et al. 2021).

\section{CMMRD}

Constitutive mismatch repair deficiency (CMMRD, MIM\#276300) is a rare autosomal recessive inherited disease caused by pathogenic variants in one of the mismatch repair genes MLH1, MSH2, MSH6 or PMS2 (Bakry et al. 2014; Wimmer et al. 2014, 2017; Suerink et al. 2019; PerezValencia et al. 2020; Aronson et al. 2021; Duorno et al. 2021). Children with CMMRD often have multiple CALM that are similar to those seen in patients with NF1 or Legius syndrome. Hence, CMMRD should be considered when arriving at a differential diagnosis of children presenting with multiple CALM. Some patients with CMMRD even meet the clinical NIH diagnostic criteria for NF1 (Wimmer et al. 2014). It is important to distinguish between these conditions because CMMRD is associated with a high risk of childhood malignancy unlike NF1 and Legius syndrome (Bakry et al. 2014; Wimmer et al. 2014, 2017; Suerink et al. 2019; Perez-Valencia et al. 2020; Aronson et al. 2021; Duorno et al. 2021).

The occurrence of CALM in patients with CMMRD is intriguing. Most likely, CALM (and other NFl-associated symptoms such as neurofibromas or freckling) in patients with CMMRD are caused by postzygotic NF1 mutations. This has been concluded from the observation that several patients with CMMRD exhibited a segmental distribution of these lesions and from the detection of postzygotic NFI variants causing somatic mosaicism in CMMRD patients (Wang et al. 1999; Auclair et al. 2007; Alotaibi et al. 2008). The large size of the $N F 1$ gene and its high mutation rate, indicated by the fact that at least $50 \%$ of all NF1 cases are sporadic, may render the $N F 1$ gene highly susceptible to postzygotic mutations in the absence of MMR activity (Wang et al. 1999). The need for a differential diagnosis to distinguish between CMMRD, NF1 and Legius syndrome as well as mosaic NF1 has been emphasised in the revised diagnostic criteria for NF1 (Legius et al. 2021).

The 1988 NIH clinical diagnostic criteria for NF1 included the criterion "a first-degree relative NF1 (parent, sib or offspring) diagnosed with NF1" (Table 1). This criterion has been restricted to "parent", and "sib or offspring" has been removed from the revised criteria by Legius et al. (2021) (Table 1). An affected sibling no longer qualifies as a criterion for NF1 since if only siblings are affected, a diagnosis of CMMRD would also be possible. Additionally, having affected offspring no longer qualifies as a diagnostic criterion for constitutional NF1. If an adult person only has one NF1 criterion in addition to an affected child fulfilling the diagnostic criteria, this person is likely to have mosaic NF which should be differentiated from constitutional NF1. Legius et al. (2021) stated that the revised criterion, which only includes "parent with NF1", is specific enough to correctly diagnose most offspring presenting with one diagnostic criterion as having NF1.

Table 4 Diagnostic criteria for Legius syndrome according to Legius et al. (2021)

(A) The diagnostic criteria for Legius syndrome are met in an individual who does not have a parent diagnosed with Legius syndrome if both of the following criteria are present:

$\geq 6$ Café-au-lait macules bilaterally distributed and no other NF1-related diagnostic criteria except for axillary or inguinal freckling ${ }^{\mathrm{a}}$

A heterozygous pathogenic variant in SPRED1 with a variant allele fraction of 50\% in an apparently normal tissue such as white blood cells

(B) A child of a parent who meets the diagnostic criteria specified in (A) merits a diagnosis of Legius syndrome if one or more of the criteria in (A) are present

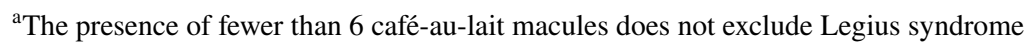




\section{Mosaicism}

Somatic mosaicism caused by a postzygotic pathogenic $N F 1$ variant may be responsible for isolated CALM in patients without a family history of NF1. In general, mosaicism in NF1 may either be associated with a generalized form of the disease, with symptoms located in a disseminated manner and not restricted to a specific body part. Alternatively, mosaic NF1 can present in a segmental form characterized by symptoms such as CALM limited to one side of the body or one specific limb or segment. Mosaic NF1 is often associated with a milder disease manifestation than generalized NF1 caused by a germline pathogenic $N F 1$ variant and may be responsible for an oligosymptomatic disease manifestation (Ruggieri and Huson 2001; Tinschert et al. 2000; García-Romero et al. 2016; Ejerskov et al. 2021). Remarkably, many children with segmental NF1 have only localized pigmentary changes (Listernick et al. 2003; Lara-Corrales et al. 2017; Hom et al. 2020). In addition to the revised diagnostic criteria for NF1 and Legius syndrome, Legius et al. (2021) also recommended diagnostic criteria for the mosaic forms of both disorders. According to Legius et al. (2021), mosaic NF1 in a patient with clinical signs of the disease is confirmed if the patient harbours a heterozygous pathogenic NFI variant in unaffected tissue such as blood but in significantly fewer than $100 \%$ of cells (as indicated by a variant allele fraction of $<50 \%$ ). Further, mosaic NF1 is confirmed if an identical first hit pathogenic NFl variant is identified in two or more anatomically unrelated lesions such as CALM or neurofibromas in the absence of this pathogenic NF1 variant in unaffected tissue such as blood. The retrieval of biopsies taken from small children suspected of having NF1 could be regarded as problematic but has been successfully applied to diagnose small plexiform neurofibromas below irregular shaped CALM or hyperpigmented regions by histopathological analysis which served to confirm the diagnosis of NF1 in children with a mean age of 6.7 years (range: 6 months-18 years) (García-Martínez et al. 2021).

\section{Conclusion/summary}

The revised diagnostic criteria for NF1 comprise all the clinical criteria included in the NIH diagnostic criteria from 1988 which proved to be very helpful for the diagnosis of NF1, particularly in older children and adults. Additionally, the revised diagnostic criteria include choroidal anomalies as a new ophthalmic criterion of high importance since choroidal anomalies may be observed earlier than Lisch nodules and have a high sensitivity and specificity for NF1. Furthermore, the revised diagnostic criteria for NF1 include the detection of a pathogenic variant of the $N F 1$ gene as a separate diagnostic criterion. Taken together, the revised diagnostic criteria for NF1 may facilitate an early diagnosis, particularly in young children with isolated CALM and without a parent with NF1. The revised diagnostic criteria for NF1, together with the newly formulated diagnostic criteria for Legius syndrome which include genetic testing for pathogenic variants in SPREDI, promise to facilitate the differential diagnosis of both disorders at an early age.

Author contributions HKS collected the data; HKS and DNC wrote and edited the manuscript in equal parts.

Funding Open Access funding enabled and organized by Projekt DEAL.

\section{Declarations}

Conflict of interest The authors declare that they have no conflict of interest.

Data availability The manuscript does not have associated data.

Code availability The manuscript does not include software application or custom codes.

Open Access This article is licensed under a Creative Commons Attribution 4.0 International License, which permits use, sharing, adaptation, distribution and reproduction in any medium or format, as long as you give appropriate credit to the original author(s) and the source, provide a link to the Creative Commons licence, and indicate if changes were made. The images or other third party material in this article are included in the article's Creative Commons licence, unless indicated otherwise in a credit line to the material. If material is not included in the article's Creative Commons licence and your intended use is not permitted by statutory regulation or exceeds the permitted use, you will need to obtain permission directly from the copyright holder. To view a copy of this licence, visit http://creativecommons.org/licenses/by/4.0/.

\section{References}

Alotaibi H, Ricciardone MD, Ozturk M (2008) Homozygosity at variant $M L H 1$ can lead to secondary mutation in NF1, neurofibromatosis type I and early onset leukemia. Mutat Res 637:209-214. https://doi.org/10.1016/j.mrfmmm.2007.08.003

Alper J, Holmes LB, Mihm MC Jr (1979) Birthmarks with serious medical significance: nevocellular nevi, sebaceous nevi, and multiple café au lait spots. J Pediatr 95:696-700

Alwan S, Tredwell SJ, Friedman JM (2005) Is osseous dysplasia a primary feature of neurofibromatosis 1 (NF1)? Clin Genet 67:378390. https://doi.org/10.1111/j.1399-0004.2005.00410.x

Anderson S (2020) Café au lait macules and associated genetic syndromes. J Pediatr Health Care 34:71-81. https://doi.org/10. 1016/j.pedhc.2019.05.001

Aronson M, Colas C, Shuen A, Hampel H, Foulkes WD, Baris Feldman H, Goldberg Y, Muleris M, Wolfe Schneider K, McGee RB, Jasperson K, Rangaswami A, Brugieres L, Tabori U (2021) Diagnostic criteria for constitutional mismatch repair deficiency (CMMRD): recommendations from the international consensus 
working group. J Med Genet 23:jmedgenet-2020-107627. https:// doi.org/10.1136/jmedgenet-2020-107627

Auclair J, Leroux D, Desseigne F, Lasset C, Saurin JC, Joly MO, Pinson S, Xu XL, Montmain G, Ruano E, Navarro C, Puisieux A, Wang Q (2007) Novel biallelic mutations in MSH6 and PMS2 genes: gene conversion as a likely cause of $P M S 2$ gene inactivation. Hum Mutat 28:1084-1090. https://doi.org/10.1002/humu. 20569

Avery RA, Katowitz JA, Fisher MJ, Heidary G, Dombi E, Packer RJ, Widemann BC; OPPN Working Group (2017) Orbital/periorbital plexiform neurofibromas in children with neurofibromatosis type 1: multidisciplinary recommendations for care. Ophthalmology 124:123-132. https://doi.org/10.1016/j.ophtha.2016.09.020

Bakry D, Aronson M, Durno C, Rimawi H, Farah R, Alharbi QK, Alharbi M, Shamvil A, Ben-Shachar S, Mistry M, Constantini S, Dvir R, Qaddoumi I, Gallinger S, Lerner-Ellis J, Pollett A, Stephens D, Kelies S, Chao E, Malkin D, Bouffet E, Hawkins C, Tabori U (2014) Genetic and clinical determinants of constitutional mismatch repair deficiency syndrome: report from the constitutional mismatch repair deficiency consortium. Eur J Cancer 50:987-996. https://doi.org/10.1016/j.ejca.2013.12.005

Ben-Shachar S, Dubov T, Toledano-Alhadef H, Mashiah J, Sprecher E, Constantini S, Leshno M, Messiaen LM (2017) Predicting neurofibromatosis type 1 risk among children with isolated café-au-lait macules. J Am Acad Dermatol 76:1077-1083.e3. https://doi.org/10.1016/j.jaad.2017.02.027

Bergoug M, Doudeau M, Godin F, Mosrin C, Vallée B, Bénédetti H (2020) Neurofibromin structure, functions and regulation. Cells 9:2365. https://doi.org/10.3390/cells9112365

Bernier A, Larbrisseau A, Perreault S (2016) Café-au-lait macules and neurofibromatosis type 1: a review of the literature. Pediatr Neurol 60:24-29.e1. https://doi.org/10.1016/j.pediatrneu rol.2016.03.003

Blanchard G, Lafforgue MP, Lion-François L, Kemlin I, Rodriguez D, Castelnau P, Carneiro M, Meyer P, Rivier F, Barbarot S, Chaix Y, NF France network (2016) Systematic MRI in NF1 children under six years of age for the diagnosis of optic pathway gliomas. Study and outcome of a French cohort. Eur J Paediatr Neurol 20:275-281. https://doi.org/10.1016/j.ejpn. 2015.12.002

Boley S, Sloan JL, Pemov A, Stewart DR (2009) A quantitative assessment of the burden and distribution of Lisch nodules in adults with neurofibromatosis type 1. Invest Ophthalmol vis Sci 50:5035-5043. https://doi.org/10.1167/iovs.09-3650

Brems H, Legius E (2013) Legius syndrome, an update. Molecular pathology of mutations in SPRED1. Keio J Med 62:107-112. https://doi.org/10.2302/kjm.2013-0002-re

Brems H, Chmara M, Sahbatou M, Denayer E, Taniguchi K, Kato R, Somers R, Messiaen L, De Schepper S, Fryns JP, Cools J, Marynen P, Thomas G, Yoshimura A, Legius E (2007) Germline loss-of-function mutations in SPRED1 cause a neurofibromatosis 1-like phenotype. Nat Genet 39:1120-1126. https://doi.org/10. 1038/ng2113

Brems H, Beert E, de Ravel T, Legius E (2009) Mechanisms in the pathogenesis of malignant tumours in neurofibromatosis type 1. Lancet Oncol 10:508-515. https://doi.org/10.1016/S14702045(09)70033-6

Brems H, Pasmant E, Van Minkelen R, Wimmer K, Upadhyaya M, Legius E, Messiaen L (2012) Review and update of SPRED1 mutations causing Legius syndrome. Hum Mutat 33:1538-1546. https://doi.org/10.2302/kjm.2013-0002-re

Burkitt Wright EM, Sach E, Sharif S, Quarrell O, Carroll T, Whitehouse RW, Upadhyaya M, Huson SM, Evans DG (2013) Can the diagnosis of NF1 be excluded clinically? A lack of pigmentary findings in families with spinal neurofibromatosis demonstrates a limitation of clinical diagnosis. J Med Genet 50:606-613. https:// doi.org/10.1136/jmedgenet-2013-101648

Burwell RG, James NJ, Johnston DI (1982) Café-au-lait spots in schoolchildren. Arch Dis Child 57:631-632

Cassiman C, Legius E, Spileers W, Casteels I (2013) Ophthalmological assessment of children with neurofibromatosis type 1. Eur J Pediatr 172:1327-1333. https://doi.org/10.1007/s00431-013-2035-2

Cassiman C, Casteels I, Jacob J, Plasschaert E, Brems H, Dubron K, Keer KV, Legius E (2017) Choroidal abnormalities in café-aulait syndromes: a new differential diagnostic tool? Clin Genet 91:529-535. https://doi.org/10.1111/cge.12873

Castellanos E, Rosas I, Negro A, Gel B, Alibés A, Baena N, Pineda M, Pi G, Pintos G, Salvador H, Lázaro C, Blanco I, Vilageliu L, Brems H, Grinberg D, Legius E, Serra E (2020) Mutational spectrum by phenotype: panel-based NGS testing of patients with clinical suspicion of RASopathy and children with multiple caféau-lait macules. Clin Genet 97:264-275. https://doi.org/10.1111/ cge. 13649

Chauvel-Picard J, Lion-Francois L, Beuriat PA, Paulus C, Szathmari A, Mottolese C, Gleizal A, Di Rocco F (2020) Craniofacial bone alterations in patients with neurofibromatosis type 1 . Childs Nerv Syst 36:2391-2399. https://doi.org/10.1007/s00381-020-04749-6

Cnossen MH, Smit FJ, de Goede-Bolder A, Frets PG, Duivenvoorden HJ, Niermeijer MF (1997) Diagnostic delay in neurofibromatosis type 1. Eur J Pediatr 156:482-487. https://doi.org/10.1007/ s004310050644

Cnossen MH, de Goede-Bolder A, van den Broek KM, Waasdorp CM, Oranje AP, Stroink H, Simonsz HJ, van den Ouweland AM, Halley DJ, Niermeijer MF (1998) A prospective 10 year follow up study of patients with neurofibromatosis type 1. Arch Dis Child 78:408-412. https://doi.org/10.1136/adc.78.5.408

De Schepper S, Maertens O, Callens T, Naeyaert JM, Lambert J, Messiaen L (2008) Somatic mutation analysis in NF1 café au lait spots reveals two $N F 1$ hits in the melanocytes. J Invest Dermatol 128:1050-1053. https://doi.org/10.1038/sj.jid.5701095

DeBella K, Szudek J, Friedman JM (2000) Use of the National Institutes of Health criteria for diagnosis of neurofibromatosis 1 in children. Pediatrics 105:608-614. https://doi.org/10.1542/peds. 105.3.608

Denayer E, Legius E (2020) Legius syndrome and its relationship with neurofibromatosis type 1. Acta Derm Venereol 100:adv00093. https://doi.org/10.2340/00015555-3429

Dunzendorfer-Matt T, Mercado EL, Maly K, McCormick F, Scheffzek K (2016) The neurofibromin recruitment factor Spred1 binds to the GAP related domain without affecting Ras inactivation. Proc Natl Acad Sci USA 113:7497-7502. https://doi.org/10. 1073/pnas. 1607298113

Durno C, Ercan AB, Bianchi V, Edwards M, Aronson M, Galati M, Atenafu EG, Abebe-Campino G, Al-Battashi A, Alharbi M, Azad VF, Baris HN, Basel D, Bedgood R, Bendel A, Ben-Shachar S, Blumenthal DT, Blundell M, Bornhorst M, Bronsema A, Cairney E, Rhode S, Caspi S, Chamdin A, Chiaravalli S, Constantini S, Crooks B, Das A, Dvir R, Farah R, Foulkes WD, Frenkel Z, Gallinger B, Gardner S, Gass D, Ghalibafian M, Gilpin C, Goldberg Y, Goudie C, Hamid SA, Hampel H, Hansford JR, Harlos C, Hijiya N, Hsu S, Kamihara J, Kebudi R, Knipstein J, Koschmann C, Kratz C, Larouche V, Lassaletta A, Lindhorst S, Ling SC, Link MP, Loret De Mola R, Luiten R, Lurye M, Maciaszek JL, MagimairajanIssai V, Maher OM, Massimino M, McGee RB, Mushtaq N, Mason G, Newmark M, Nicholas G, Nichols KE, Nicolaides T, Opocher E, Osborn M, Oshrine B, Pearlman R, Pettee D, Rapp J, Rashid M, Reddy A, Reichman L, Remke M, Robbins G, Roy S, Sabel M, Samuel D, Scheers I, Schneider KW, Sen S, Stearns D, Sumerauer D, Swallow C, Taylor L, Thomas G, Toledano H, Tomboc P, Van Damme A, Winer I, Yalon M, Yen LY, Zapotocky 
M, Zelcer S, Ziegler DS, Zimmermann S, Hawkins C, Malkin D, Bouffet E, Villani A, Tabori U (2021) Survival benefit for individuals with constitutional mismatch repair deficiency undergoing surveillance. J Clin Oncol 39:2779-2790. https://doi.org/ 10.1200/JCO.20.02636

Ejerskov C, Raundahl M, Gregersen PA, Handrup MM (2021) Clinical features and disease severity in patients with mosaic neurofibromatosis type 1: a single-center study and literature review. Orphanet J Rare Dis 16(1):180. https://doi.org/10.1186/ s13023-021-01796-3

Evans DG, Bowers N, Burkitt-Wright E, Miles E, Garg S, Scott-Kitching V, Penman-Splitt M, Dobbie A, Howard E, Ealing J, Vassalo G, Wallace AJ, Newman W, Northern UK NF1 Research Network, Huson SM (2016) Comprehensive RNA analysis of the NF1 gene in classically affected NF1 affected individuals meeting NIH criteria has high sensitivity and mutation negative testing is reassuring in isolated cases with pigmentary features only. EBioMedicine 7:212-220. https://doi.org/10.1016/j.ebiom. 2016.04.005

Friedman JM, Birch PH (1997) Type 1 neurofibromatosis: a descriptive analysis of the disorder in 1,728 patients. Am J Med Genet 70:138-143

Friedrich RE, Nuding MA (2016) Optic pathway glioma and cerebral focal abnormal signal intensity in patients with neurofibromatosis type 1: characteristics, treatment choices and follow-up in 134 affected individuals and a brief review of the literature. Anticancer Res 36:4095-4121

García-Martínez FJ, Azorín D, Duat-Rodríguez A, Hernández-Martín Á (2021) Congenital cutaneous neurofibromas in neurofibromatosis type 1: clinicopathological features in early infancy. J Dtsch Dermatol Ges 19:73-80. https://doi.org/10.1111/ddg.14322

García-Romero MT, Parkin P, Lara-Corrales I (2016) Mosaic neurofibromatosis type 1: a systematic review. Pediatr Dermatol 33:9-17. https://doi.org/10.1111/pde.12673

Giugliano T, Santoro C, Torella A, Del Vecchio BF, Grandone A, Onore ME, Melone MAB, Straccia G, Melis D, Piccolo V, Limongelli G, Buono S, Perrotta S, Nigro V, Piluso G (2019) Clinical and genetic findings in children with neurofibromatosis type 1, Legius syndrome, and other related neurocutaneous disorders. Genes (basel) 10:580. https://doi.org/10.3390/genes 10080580

Goktas S, Sakarya Y, Ozcimen M, Alpfidan I, Uzun M, Sakarya R, Yarbag A (2014) Frequency of choroidal abnormalities in pediatric patients with neurofibromatosis type 1. J Pediatr Ophthalmol Strabismus 51:204-208. https://doi.org/10.3928/0191391320140513-02

Hom GL, Moodley S, Rothner AD, Moodley M (2020) The clinical spectrum of mosaic neurofibromatosis in children and adolescents. J Child Neurol 35:242-246. https://doi.org/10.1177/08830 73819889713

Huson SM, Compston DAS, Harper PS (1989) A genetic study of von Recklinghausen neurofibromatosis in south east Wales II: guidelines for genetic counselling. J Med Genet 26:712-721

Imbard A, Pasmant E, Sabbagh A, Luscan A, Soares M, Goussard P, Blanché H, Laurendeau I, Ferkal S, Vidaud M, Pinson S, Bellanne-Chantelot C, Vidaud D, Wolkenstein P, Members of the NF France Network, Parfait B (2015) NF1 single and multiexons copy number variations in neurofibromatosis type 1 . J Hum Genet 60:221-224. https://doi.org/10.1038/jhg.2015.6

Jacquemin C, Bosley TM, Liu D, Svedberg H, Buhaliqa A (2002) Reassessment of sphenoid dysplasia associated with neurofibromatosis type 1. AJNR Am J Neuroradiol 23:644-648

Jett K, Friedman JM (2010) Clinical and genetic aspects of neurofibromatosis 1. Genet Med 12:1-11. https://doi.org/10.1097/GIM. 0b013e3181bf15e3
Jha SK, Mendez MD (2020) Café au lait macules. StatPearls Publishing, Treasure Island

Jobling RK, Lara-Corrales I, Hsiao MC, Shugar A, Hedges S, Messiaen L, Kannu P (2017) Mosaicism for a SPRED1 deletion revealed in a patient with clinically suspected mosaic neurofibromatosis. $\mathrm{Br}$ J Dermatol 176:1077-1078. https://doi.org/10.1111/bjd.14873

Kehrer-Sawatzki H, Cooper DN (2021) Classification of NF1 microdeletions and its importance for establishing genotype/ phenotype correlations in patients with NF1 microdeletions. Hum Genet 140(12):1635-1649. https://doi.org/10.1007/ s00439-021-02363-3

Koczkowska M, Chen Y, Callens T, Gomes A, Sharp A, Johnson S, Hsiao MC, Chen Z, Balasubramanian M, Barnett CP, Becker TA, Ben-Shachar S, Bertola DR, Blakeley JO, Burkitt-Wright EMM, Callaway A, Crenshaw M, Cunha KS, Cunningham M, D’Agostino MD, Dahan K, De Luca A, Destrée A, Dhamija R, Eoli M, Evans DGR, Galvin-Parton P, George-Abraham JK, Gripp KW, Guevara-Campos J, Hanchard NA, Hernández-Chico C, Immken L, Janssens S, Jones KJ, Keena BA, Kochhar A, Liebelt J, Martir-Negron A, Mahoney MJ, Maystadt I, McDougall C, McEntagart M, Mendelsohn N, Miller DT, Mortier G, Morton J, Pappas J, Plotkin SR, Pond D, Rosenbaum K, Rubin K, Russell L, Rutledge LS, Saletti V, Schonberg R, Schreiber A, Seidel M, Siqveland E, Stockton DW, Trevisson E, Ullrich NJ, Upadhyaya M, van Minkelen R, Verhelst H, Wallace MR, Yap YS, Zackai E, Zonana J, Zurcher V, Claes K, Martin Y, Korf BR, Legius E, Messiaen LM (2018) Genotype-phenotype correlation in NF1: evidence for a more severe phenotype associated with missense mutations affecting NF1 Codons 844-848. Am J Hum Genet 102:69-87. https://doi.org/10.1016/j.ajhg.2017.12.001

Koczkowska M, Callens T, Gomes A, Sharp A, Chen Y, Hicks AD, Aylsworth AS, Azizi AA, Basel DG, Bellus G, Bird LM, Blazo MA, Burke LW, Cannon A, Collins F, DeFilippo C, Denayer E, Digilio MC, Dills SK, Dosa L, Greenwood RS, Griffis C, Gupta P, Hachen RK, Hernández-Chico C, Janssens S, Jones KJ, Jordan JT, Kannu P, Korf BR, Lewis AM, Listernick RH, Lonardo F, Mahoney MJ, Ojeda MM, McDonald MT, McDougall C, Mendelsohn N, Miller DT, Mori M, Oostenbrink R, Perreault S, Pierpont ME, Piscopo C, Pond DA, Randolph LM, Rauen KA, Rednam S, Rutledge SL, Saletti V, Schaefer GB, Schorry EK, Scott DA, Shugar A, Siqveland E, Starr LJ, Syed A, Trapane PL, Ullrich NJ, Wakefield EG, Walsh LE, Wangler MF, Zackai E, Claes KBM, Wimmer K, van Minkelen R, De Luca A, Martin Y, Legius E, Messiaen LM (2019) Expanding the clinical phenotype of individuals with a 3-bp in-frame deletion of the NF1 gene (c.2970_2972del): an update of genotype-phenotype correlation. Genet Med 21:867-876. https://doi.org/10.1038/ s41436-018-0269-0

Koczkowska M, Callens T, Chen Y, Gomes A, Hicks AD, Sharp A, Johns E, Uhas KA, Armstrong L, Bosanko KA, Babovic-Vuksanovic D, Baker L, Basel DG, Bengala M, Bennett JT, Chambers C, Clarkson LK, Clementi M, Cortés FM, Cunningham M, D’Agostino MD, Delatycki MB, Digilio MC, Dosa L, Esposito S, Fox S, Freckmann ML, Fauth C, Giugliano T, Giustini S, Goetsch A, Goldberg Y, Greenwood RS, Griffis C, Gripp KW, Gupta P, Haan E, Hachen RK, Haygarth TL, Hernández-Chico C, Hodge K, Hopkin RJ, Hudgins L, Janssens S, Keller K, KellyMancuso G, Kochhar A, Korf BR, Lewis AM, Liebelt J, Lichty A, Listernick RH, Lyons MJ, Maystadt I, Martinez Ojeda M, McDougall C, McGregor LK, Melis D, Mendelsohn N, Nowaczyk MJM, Ortenberg J, Panzer K, Pappas JG, Pierpont ME, Piluso G, Pinna V, Pivnick EK, Pond DA, Powell CM, Rogers C, Ruhrman Shahar N, Rutledge SL, Saletti V, Sandaradura SA, Santoro C, Schatz UA, Schreiber A, Scott DA, Sellars EA, Sheffer R, Siqveland E, Slopis JM, Smith R, Spalice A, Stockton DW, Streff H, Theos A, Tomlinson GE, Tran G, Trapane PL, 
Trevisson E, Ullrich NJ, Van den Ende J, Schrier Vergano SA, Wallace SE, Wangler MF, Weaver DD, Yohay KH, Zackai E, Zonana J, Zurcher V, Claes KBM, Eoli M, Martin Y, Wimmer K, De Luca A, Legius E, Messiaen LM (2020) Clinical spectrum of individuals with pathogenic NF1 missense variants affecting p.Met1149, p.Arg 1276, and p.Lys 1423: genotype-phenotype study in neurofibromatosis type 1. Hum Mutat 41:299-315. https://doi.org/10.1002/humu.23929

Korf BR (1992) Diagnostic outcome in children with multiple café au lait spots. Pediatrics 90:924-927

Lalor L, Davies OMT, Basel D, Siegel DH (2020) Café au lait spots: when and how to pursue their genetic origins. Clin Dermatol 38:421-431. https://doi.org/10.1016/j.clindermatol.2020.03.005

Lammert M, Friedman JM, Kluwe L, Mautner VF (2005) Prevalence of neurofibromatosis 1 in German children at elementary school enrollment. Arch Dermatol 141:71-74. https://doi.org/10.1001/ archderm.141.1.71

Lara-Corrales I, Moazzami M, García-Romero MT, Pope E, Parkin P, Shugar A, Kannu P (2017) Mosaic neurofibromatosis type 1 in children: a single-institution experience. J Cutan Med Surg 21:379-382. https://doi.org/10.1177/1203475417708163

Laycock-van Spyk S, Jim HP, Thomas L, Spurlock G, Fares L, PalmerSmith S, Kini U, Saggar A, Patton M, Mautner V, Pilz DT, Upadhyaya M (2011) Identification of five novel SPRED1 germline mutations in Legius syndrome. Clin Genet 80:93-96. https://doi. org/10.1111/j.1399-0004.2010.01618.x

Legius E, Messiaen L, Wolkenstein P, Pancza P, Avery RA, Berman Y, Blakeley J, Babovic-Vuksanovic D, Cunha KS, Ferner R, Fisher MJ, Friedman JM, Gutmann DH, Kehrer-Sawatzki H, Korf BR, Mautner VF, Peltonen S, Rauen KA, Riccardi V, Schorry E, Stemmer-Rachamimov A, Stevenson DA, Tadini G, Ullrich NJ, Viskochil D, Wimmer K, Yohay K, International Consensus Group on Neurofibromatosis Diagnostic Criteria (I-NF-DC), Huson SM, Evans DG, Plotkin SR (2021) Revised diagnostic criteria for neurofibromatosis type 1 and Legius syndrome: an international consensus recommendation. Genet Med 23:15061513. https://doi.org/10.1038/s41436-021-01170-5

Listernick R, Charrow J, Greenwald M, Mets M (1994) Natural history of optic pathway tumors in children with neurofibromatosis type 1: a longitudinal study. J Pediatr 125:63-66. https://doi.org/10. 1016/s0022-3476(94)70122-9

Listernick R, Mancini AJ, Charrow J (2003) Segmental neurofibromatosis in childhood. Am J Med Genet A 121A:132-135. https:// doi.org/10.1002/ajmg.a.20183

Listernick R, Ferner RE, Liu GT, Gutmann DH (2007) Optic pathway gliomas in neurofibromatosis-1: controversies and recommendations. Ann Neurol 61:189-198. https://doi.org/10.1002/ana. 21107

Lorenzo C, McCormick F (2020) SPRED proteins and their roles in signal transduction, development, and malignancy. Genes Dev 34:1410-1421. https://doi.org/10.1101/gad.341222.120

Lubs ML, Bauer MS, Formas ME, Djokic B (1991) Lisch nodules in neurofibromatosis type 1. N Engl J Med 324:1264-1266. https:// doi.org/10.1056/NEJM199105023241807

Maertens O, Brems H, Vandesompele J, De Raedt T, Heyns I, Rosenbaum T, De Schepper S, De Paepe A, Mortier G, Janssens S, Speleman F, Legius E, Messiaen L (2006) Comprehensive NF1 screening on cultured Schwann cells from neurofibromas. Hum Mutat 27:1030-1040. https://doi.org/10.1002/humu.20389

Maertens O, De Schepper S, Vandesompele J, Brems H, Heyns I, Janssens S, Speleman F, Legius E, Messiaen L (2007) Molecular dissection of isolated disease features in mosaic neurofibromatosis type 1. Am J Hum Genet 81:243-251. https://doi.org/10.1086/ 519562
Messiaen L (2020) Molecular diagnosis of NF1. In: Tadini G, Legius E, Brems H (eds) Multidiscipilinary approach to neurofibromatosis 1. Springer, Cham, pp 15-34

Messiaen LM, Callens T, Mortier G, Beysen D, Vandenbroucke I, Van Roy N, Speleman F, Paepe AD (2000) Exhaustive mutation analysis of the NF1 gene allows identification of $95 \%$ of mutations and reveals a high frequency of unusual splicing defects. Hum Mutat 15:541-555. https://doi.org/10.1002/1098-1004(200006) 15:6\%3c541::AID-HUMU6\%3e3.0.CO;2-N

Messiaen L, Yao S, Brems H, Callens T, Sathienkijkanchai A, Denayer E, Spencer E, Arn P, Babovic-Vuksanovic D, Bay C, Bobele G, Cohen BH, Escobar L, Eunpu D, Grebe T, Greenstein R, Hachen R, Irons M, Kronn D, Lemire E, Leppig K, Lim C, McDonald M, Narayanan V, Pearn A, Pedersen R, Powell B, Shapiro LR, Skidmore D, Tegay D, Thiese H, Zackai EH, Vijzelaar R, Taniguchi K, Ayada T, Okamoto F, Yoshimura A, Parret A, Korf B, Legius E (2009) Clinical and mutational spectrum of neurofibromatosis type 1-like syndrome. JAMA 302:2111-2118. https://doi.org/10. 1001/jama.2009.1663

Neurofibromatosis (1988) Conference statement: National Institutes of Health Consensus Development Conference. Arch Neurol 45:575-578

Nguyen R, Kluwe L, Fuensterer C, Kentsch M, Friedrich RE, Mautner VF (2011) Plexiform neurofibromas in children with neurofibromatosis type 1: frequency and associated clinical deficits. J Pediatr 159:652-5.e2. https://doi.org/10.1016/j.jpeds.2011.04. 008

Nicolin G, Parkin P, Mabbott D, Hargrave D, Bartels U, Tabori U, Rutka J, Buncic JR, Bouffet E (2009) Natural history and outcome of optic pathway gliomas in children. Pediatr Blood Cancer 53:1231-1237. https://doi.org/10.1002/pbc.22198

Nunley KS, Gao F, Albers AC, Bayliss SJ, Gutmann DH (2009) Predictive value of café au lait macules at initial consultation in the diagnosis of neurofibromatosis type 1. Arch Dermatol 145:883887. https://doi.org/10.1001/archdermatol.2009.169

Obringer AC, Meadows AT, Zackai EH (1989) The diagnosis of neurofibromatosis-1 in the child under the age of 6 years. Am J Dis Child 143:717-719. https://doi.org/10.1001/archpedi.1989.02150 180099028

Parrozzani R, Clementi M, Frizziero L, Miglionico G, Perrini P, Cavarzeran F, Kotsafti O, Comacchio F, Trevisson E, Convento E, Fusetti S, Midena E (2015) In vivo detection of choroidal abnormalities related to NF1: feasibility and comparison with standard NIH diagnostic criteria in pediatric patients. Invest Ophthalmol vis Sci 56:6036-6042. https://doi.org/10.1167/iovs. 14-16053

Pasmant E, Vidaud D (2016) Neurofibromatosis Type 1 molecular diagnosis: The RNA point of view. EBioMedicine 7:21-22. https://doi.org/10.1016/j.ebiom.2016.04.036

Pasmant E, Sabbagh A, Hanna N, Masliah-Planchon J, Jolly E, Goussard P, Ballerini P, Cartault F, Barbarot S, Landman-Parker J, Soufir N, Parfait B, Vidaud M, Wolkenstein P, Vidaud D, France RN (2009) SPRED1 germline mutations caused a neurofibromatosis type 1 overlapping phenotype. J Med Genet 46:425-430. https://doi.org/10.1136/jmg.2008.065243

Pasmant E, Parfait B, Luscan A, Goussard P, Briand-Suleau A, Laurendeau I, Fouveaut C, Leroy C, Montadert A, Wolkenstein P, Vidaud M, Vidaud D (2015) Neurofibromatosis type 1 molecular diagnosis: what can NGS do for you when you have a large gene with loss of function mutations? Eur J Hum Genet 23:596-601. https://doi.org/10.1038/ejhg.2014.145

Perez-Valencia JA, Gallon R, Chen Y, Koch J, Keller M, Oberhuber K, Gomes A, Zschocke J, Burn J, Jackson MS, Santibanez-Koref M, Messiaen L, Wimmer K (2020) Constitutional mismatch repair deficiency is the diagnosis in $0.41 \%$ of pathogenic NF1/SPREDI 
variant negative children suspected of sporadic neurofibromatosis type 1. Genet Med 22:2081-2088. https://doi.org/10.1038/ s41436-020-0925-z

Pinna V, Lanari V, Daniele P, Consoli F, Agolini E, Margiotti K, Bottillo I, Torrente I, Bruselles A, Fusilli C, Ficcadenti A, Bargiacchi S, Trevisson E, Forzan M, Giustini S, Leoni C, Zampino G, Digilio MC, Dallapiccola B, Clementi M, Tartaglia M, De Luca A (2015) p.Arg1809Cys substitution in neurofibromin is associated with a distinctive $N F 1$ phenotype without neurofibromas. Eur J Hum Genet 23:1068-1071. https://doi.org/10.1038/ejhg. 2014.243

Plon SE, Eccles DM, Easton D, Foulkes WD, Genuardi M, Greenblatt MS, Hogervorst FB, Hoogerbrugge N, Spurdle AB, Tavtigian SV, IARC Unclassified Genetic Variants Working Group (2008) Sequence variant classification and reporting: recommendations for improving the interpretation of cancer susceptibility genetic test results. Hum Mutat 29:1282-1291. https://doi.org/10.1002/ humu. 20880

Prada CE, Rangwala FA, Martin LJ, Lovell AM, Saal HM, Schorry EK, Hopkin RJ (2012) Pediatric plexiform neurofibromas: impact on morbidity and mortality in neurofibromatosis type 1 . J Pediatr 160:461-467. https://doi.org/10.1016/j.jpeds.2011.08.051

Pros E, Gómez C, Martín T, Fábregas P, Serra E, Lázaro C (2008) Nature and mRNA effect of 282 different NF1 point mutations: focus on splicing alterations. Hum Mutat 29:E173-193. https:// doi.org/10.1002/humu.20826

Quintáns B, Pardo J, Campos B, Barros F, Volpini V, Carracedo A, Sobrido MJ (2011) Neurofibromatosis without neurofibromas: confirmation of a genotype-phenotype correlation and implications for genetic testing. Case Rep Neurol 3:86-90. https://doi. org/10.1159/000327557

Rauen KA (2013) The RASopathies. Annu Rev Genomics Hum Genet 14:355-369. https://doi.org/10.1146/annur ev-genom-091212-153523

Riccardi VM (1981) Von Reckinghausen neurofibromatosis. N Engl J Med 305:1617-1626

Richards S, Aziz N, Bale S, Bick D, Das S, Gastier-Foster J, Grody WW, Hegde M, Lyon E, Spector E, Voelkerding K, Rehm HL, Laboratory Quality Assurance Committee ACMG (2015) Standards and guidelines for the interpretation of sequence variants: a joint consensus recommendation of the American College of Medical Genetics and Genomics and the Association for Molecular Pathology. Genet Med 17:405-424. https:// doi.org/10.1038/gim.2015.30

Rojnueangnit K, Xie J, Gomes A, Sharp A, Callens T, Chen Y, Liu Y, Cochran M, Abbott MA, Atkin J, Babovic-Vuksanovic D, Barnett CP, Crenshaw M, Bartholomew DW, Basel L, Bellus G, Ben-Shachar S, Bialer MG, Bick D, Blumberg B, Cortes F, David KL, Destree A, Duat-Rodriguez A, Earl D, Escobar L, Eswara M, Ezquieta B, Frayling IM, Frydman M, Gardner K, Gripp KW, Hernández-Chico C, Heyrman K, Ibrahim J, Janssens S, Keena BA, Llano-Rivas I, Leppig K, McDonald M, Misra VK, Mulbury J, Narayanan V, Orenstein N, Galvin-Parton P, Pedro H, Pivnick EK, Powell CM, Randolph L, Raskin S, Rosell J, Rubin K, Seashore M, Schaaf CP, Scheuerle A, Schultz M, Schorry E, Schnur R, Siqveland E, Tkachuk A, Tonsgard J, Upadhyaya M, Verma IC, Wallace S, Williams C, Zackai E, Zonana J, Lazaro C, Claes K, Korf B, Martin Y, Legius E, Messiaen L (2015) High incidence of noonan syndrome features including short stature and pulmonic stenosis in patients carrying NF1 missense mutations affecting p.Arg1809: genotype-phenotype correlation. Hum Mutat 36:1052-1063. https://doi.org/10.1002/humu.22832

Ruggieri M, Huson SM (2001) The clinical and diagnostic implications of mosaicism in the neurofibromatoses. Neurology 56:14331443. https://doi.org/10.1212/wnl.56.11.1433
Sabbagh A, Pasmant E, Imbard A, Luscan A, Soares M, Blanché H, Laurendeau I, Ferkal S, Vidaud M, Pinson S, Bellanné-Chantelot C, Vidaud D, Parfait B, Wolkenstein P (2013) NF1 molecular characterization and neurofibromatosis type I genotype-phenotype correlation: the French experience. Hum Mutat 34:1510 1518. https://doi.org/10.1002/humu.22392

Sant DW, Margraf RL, Stevenson DA, Grossmann AH, Viskochil DH, Hanson H, Everitt MD, Rios JJ, Elefteriou F, Hennessey T, Mao $\mathrm{R}$ (2015) Evaluation of somatic mutations in tibial pseudarthrosis samples in neurofibromatosis type 1. J Med Genet 52:256-261

Santoro C, Pacileo G, Limongelli G, Scianguetta S, Giugliano T, Piluso G, Ragione FD, Cirillo M, Mirone G, Perrotta S (2014) LEOPARD syndrome: clinical dilemmas in differential diagnosis of RASopathies. BMC Med Genet 15:44. https://doi.org/10.1186/ 1471-2350-15-44

Santoro C, Maietta A, Giugliano T, Melis D, Perrotta S, Nigro V, Piluso G (2015) Arg (1809) substitution in neurofibromin: further evidence of a genotype-phenotype correlation in neurofibromatosis type 1. Eur J Hum Genet 23:1460-1461. https://doi. org/10.1038/ejhg.2015.93

Santos AC, Heck B, Camargo BD, Vargas FR (2016) Prevalence of café-au-lait spots in children with solid tumors. Genet Mol Biol 39:232-238. https://doi.org/10.1590/ 1678-4685-GMB-2015-0024

Serra E, Puig S, Otero D, Gaona A, Kruyer H, Ars E, Estivill X, Lazaro C (1997) Confirmation of a double-hit model for the NF1 gene in benign neurofibromas. Am J Hum Genet 61:512-519. https:// doi.org/10.1086/515504

Serra E, Rosenbaum T, Winner U, Aledo R, Ars E, Estivill X, Lenard HG, Lazaro C (2000) Schwann cells harbor the somatic NFI mutation in neurofibromas: evidence of two different Schwann cell subpopulations. Hum Mol Genet 9:3055-3064. https://doi. org $/ 10.1093 / \mathrm{hmg} / 9.20 .3055$

Shah KN (2010) The diagnostic and clinical significance of café-au-lait macules. Pediatr Clin N Am 57:1131-1153. https://doi.org/10. 1016/j.pcl.2010.07.002

Spurlock G, Bennett E, Chuzhanova N, Thomas N, Jim HP, Side L, Davies S, Haan E, Kerr B, Huson SM, Upadhyaya M (2009) SPRED1 mutations (Legius syndrome): another clinically useful genotype for dissecting the neurofibromatosis type 1 phenotype. J Med Genet 46:431-437. https://doi.org/10.1136/jmg.2008. 065474

Stenson PD, Mort M, Ball EV, Chapman M, Evans K, Azevedo L, Hayden M, Heywood S, Millar DS, Phillips AD, Cooper DN (2020) The Human Gene Mutation Database $\left(\right.$ HGMD $\left.^{\circledR}\right)$ : optimizing its use in a clinical diagnostic or research setting. Hum Genet 139:1197-1207. https://doi.org/10.1007/s00439-020-02199-3

Stevenson DA, Birch PH, Friedman JM, Viskochil DH, Balestrazzi P, Boni S, Buske A, Korf BR, Niimura M, Pivnick EK, Schorry EK, Short MP, Tenconi R, Tonsgard JH, Carey JC (1999) Descriptive analysis of tibial pseudarthrosis in patients with neurofibromatosis 1. Am J Med Genet 84:413-419. https://doi.org/10.1002/(sici) 1096-8628(19990611)84:5\%3c413::aid-ajmg5\%3e3.0.co;2-1

Stevenson DA, Zhou H, Ashrafi S, Messiaen LM, Carey JC, D'Astous JL, Santora SD, Viskochil DH (2006) Double inactivation of NFI in tibial pseudarthrosis. Am J Hum Genet 79:143-148. https:// doi.org/10.1086/504441

Stevenson DA, Viskochil DH, Schorry EK, Crawford AH, D’Astous J, Murray KA, Friedman JM, Armstrong L, Carey JC (2007) The use of anterolateral bowing of the lower leg in the diagnostic criteria for neurofibromatosis type 1. Genet Med 9:409-412. https:// doi.org/10.1097/gim.0b013e3180986e05

Stowe IB, Mercado EL, Stowe TR, Bell EL, Oses-Prieto JA, Hernández H, Burlingame AL, McCormick F (2012) A shared molecular mechanism underlies the human rasopathies Legius syndrome 
and Neurofibromatosis-1. Genes Dev 26:1421-1426. https://doi. org/10.1101/gad.190876.112

Suerink M, Ripperger T, Messiaen L, Menko FH, Bourdeaut F, Colas C, Jongmans M, Goldberg Y, Nielsen M, Muleris M, van Kouwen M, Slave I, Kratz C, Vasen HF, Brugières L, Legius E, Wimmer K (2019) Constitutional mismatch repair deficiency as a differential diagnosis of neurofibromatosis type 1: consensus guidelines for testing a child without malignancy. J Med Genet 56:53-62. https://doi.org/10.1136/jmedgenet-2018-105664

Tinschert S, Naumann I, Stegmann E, Buske A, Kaufmann D, Thiel G, Jenne DE (2000) Segmental neurofibromatosis is caused by somatic mutation of the neurofibromatosis type 1 (NF1) gene. Eur J Hum Genet 8:455-459. https://doi.org/10.1038/sj.ejhg. 5200493

Trevisson E, Cassina M, Opocher E, Vicenzi V, Lucchetta M, Parrozzani R, Miglionico G, Mardari R, Viscardi E, Midena E, Clementi M (2017) Natural history of optic pathway gliomas in a cohort of unselected patients affected by neurofibromatosis 1. J Neuro Oncol 134:279-287. https://doi.org/10.1007/ s11060-017-2517-6

Tsang E, Birch P, Friedman JM (2012) Valuing gene testing in children with possible neurofibromatosis 1. Clin Genet 82:591-593. https://doi.org/10.1111/j.1399-0004.2011.01801.x

Tucci A, Saletti V, Menni F, Cesaretti C, Scuvera G, Esposito S, Melloni G, Esposito S, Milani D, Cereda C, Cigada M, Tresoldi L, Viola F, Natacci F (2017) The absence that makes the difference: choroidal abnormalities in Legius syndrome. J Hum Genet 62:1001-1004. https://doi.org/10.1038/jhg.2017.78

Upadhyaya M, Huson SM, Davies M, Thomas N, Chuzhanova N, Giovannini S, Evans DG, Howard E, Kerr B, Griffiths S, Consoli C, Side L, Adams D, Pierpont M, Hachen R, Barnicoat A, Li H, Wallace P, Van Biervliet JP, Stevenson D, Viskochil D, Baralle D, Haan E, Riccardi V, Turnpenny P, Lazaro C, Messiaen L (2007) An absence of cutaneous neurofibromas associated with a 3-bp inframe deletion in exon 17 of the $N F 1$ gene (c.2970-2972 delAAT): evidence of a clinically significant NF1 genotype-phenotype correlation. Am J Hum Genet 80:140-151. https://doi. org/10.1086/510781

Vagge A, Camicione P, Capris C, Sburlati C, Panarello S, Calevo MG, Traverso CE, Capris P (2015) Choroidal abnormalities in neurofibromatosis type 1 detected by near-infrared reflectance imaging in paediatric population. Acta Ophthalmol 93:e667-671. https:// doi.org/10.1111/aos. 12750

Valero MC, Martín Y, Hernández-Imaz E, Marina Hernández A, Meleán G, Valero AM, Javier Rodríguez-Álvarez F, Tellería D, Hernández-Chico C (2011) A highly sensitive genetic protocol to detect NF1 mutations. J Mol Diagn 13:113-122. https://doi. org/10.1016/j.jmoldx.2010.09.002

Van Royen K, Brems H, Legius E, Lammens J, Laumen A (2016) Prevalence of neurofibromatosis type 1 in congenital pseudarthrosis of the tibia. Eur J Pediatr 175:1193-1198. https://doi.org/ $10.1007 / \mathrm{s} 00431-016-2757-\mathrm{z}$
Viola F, Villani E, Natacci F, Selicorni A, Melloni G, Vezzola D, Barteselli G, Mapelli C, Pirondini C, Ratiglia R (2012) Choroidal abnormalities detected by near-infrared reflectance imaging as a new diagnostic criterion for neurofibromatosis 1. Ophthalmology 119:369-375. https://doi.org/10.1016/j.ophtha.2011.07.046

Wakioka T, Sasaki A, Kato R, Shouda T, Matsumoto A, Miyoshi K, Tsuneoka M, Komiya S, Baron R, Yoshimura A (2001) Spred is a Sprouty-related suppressor of Ras signalling. Nature 412:647651. https://doi.org/10.1038/35088082

Wang Q, Lasset C, Desseigne F, Frappaz D, Bergeron C, Navarro C, Ruano E, Puisieux A (1999) Neurofibromatosis and early onset of cancers in hMLH1-deficient children. Cancer Res 59:294-297

Whitehouse D (1966) Diagnostic value of the café-au-lait spot in children. Arch Dis Child 41:316-319

Wimmer K, Yao S, Claes K, Kehrer-Sawatzki H, Tinschert S, De Raedt T, Legius E, Callens T, Beiglböck H, Maertens O, Messiaen L (2006) Spectrum of single- and multiexon NF1 copy number changes in a cohort of 1,100 unselected NF1 patients. Genes Chromosomes Cancer 45:265-276. https://doi.org/10.1002/gcc. 20289

Wimmer K, Kratz CP, Vasen HF, Caron O, Colas C, Entz-Werle N, Gerdes AM, Goldberg Y, Ilencikova D, Muleris M, Duval A, Lavoine N, Ruiz-Ponte C, Slave I, Burkhardt B, Brugieres L, EUConsortium Care for CMMRD (C4CMMRD) (2014) Diagnostic criteria for constitutional mismatch repair deficiency syndrome: suggestions of the European consortium "care for CMMRD" (C4CMMRD). J Med Genet 51:355-365. https://doi.org/10.1136/ jmedgenet-2014-102284

Wimmer K, Rosenbaum T, Messiaen L (2017) Connections between constitutional mismatch repair deficiency syndrome and neurofibromatosis type 1. Clin Genet 91:507-519. https://doi.org/10. $1111 /$ cge. 12904

Yao R, Wang L, Yu Y, Wang J, Shen Y (2016) Diagnostic value of multiple café-au-lait macules for neurofibromatosis 1 in Chinese children. J Dermatol 43:537-542. https://doi.org/10.1111/13468138.13169

Yasunari T, Shiraki K, Hattori H, Miki T (2000) Frequency of choroidal abnormalities in neurofibromatosis type 1. Lancet 356:988992. https://doi.org/10.1016/S0140-6736(00)02716-1

Zhu G, Zheng Y, Liu Y, Yan A, Hu Z, Yang Y, Xiang S, Li L, Chen W, Peng Y, Zhong N, Mei H (2019) Identification and characterization of NF1 and non-NF1 congenital pseudarthrosis of the tibia based on germline NF1 variants: genetic and clinical analysis of 75 patients. Orphanet J Rare Dis 14:221. https://doi.org/10.1186/ s13023-019-1196-0

Publisher's Note Springer Nature remains neutral with regard to jurisdictional claims in published maps and institutional affiliations. 